\title{
THERMAL DEGRADATION OF ORIENTAL BEECH WOOD IM- PREGNATED WITH DIFFERENT INORGANIC SALTS
}

\author{
Elif Vargun ${ }^{1}$,Ergun Baysal,^, Turkay Turkoglu ${ }^{3}$, Mehmet Yuksel $^{2}$, Hilmi Toker $^{2}$
}

\begin{abstract}
This study investigated the thermal properties of Oriental beech (Fagus orientalis) treated with $\left(\mathrm{NH}_{4}\right)_{2} \mathrm{H}-$ $\mathrm{PO}_{4}, \mathrm{~K}_{2} \mathrm{HPO}_{4}, \mathrm{NH}_{4} \mathrm{Cl}$ and $\left(\mathrm{NH}_{4}\right)_{2} \mathrm{SO}_{4}$ salts and their mixtures $(1: 1 ; \mathrm{w} / \mathrm{w})$ aqueous solutions at $3 \%$ concentrations. The effects of different inorganic salts fire retardants on the thermal degradation characteristics of wood samples were evaluated by thermogravimetric analysis (TGA). Based on the TGA curve for untreated beech wood, weight loss takes place at three distinct steps. The impregnation of inorganic salts resulted in higher char yields and additional thermal degradation steps were identified. The highest char yield $(80 \%)$ was obtained from $\left(\mathrm{NH}_{4}\right)_{2} \mathrm{HPO}_{4}-\mathrm{K}_{2} \mathrm{HPO}_{4}$ mixture impregnated sample. Salt mixtures containing phosphates $\left(\left(\mathrm{NH}_{4}\right)_{2} \mathrm{HPO}_{4}\right.$ and $\mathrm{K}_{2} \mathrm{HPO}_{4}$ ) have remarkable effects on thermal stability of beech wood, whereas $\mathrm{NH}_{4} \mathrm{Cl}$ salt lowered the decomposition temperatures and char yield.
\end{abstract}

Keywords: Fagus orientalis, thermal stability, thermogravimetric analysis, wood impregnation, wood protection.

\section{INTRODUCTION}

Flame retardancy property of products had become mandatory for public security, especially in public transportation, aircraft and automobile parts, buildings, housing and even in baby blankets (Ohashi et al. 2017, Salman et al. 2014). Wood is an easily flammable material and its thermal stability can be improved by different techniques. The wood components (hemicellulose, cellulose and lignin) start to degrade when wood is subjected to heat. At around $200^{\circ} \mathrm{C}$, acetic acid is released from hemicelluloses by hydrolysis and this acid acts as a catalyst for cleavage of cellulose chains. At lower temperatures, volatile compounds are generated from hemicellulose and cellulose carbohydrates. When the temperatures reach high levels, the levoglucosan is formed, which can be further decomposed into volatile and flammable products and lignin starts to decompose (Kartal et al. 2007). Flame retardant/wood preservative systems may be impregnated into wood by non-pressure dipping, diffusion and vacuum or pressure processes (Thevenon et al. 2009).

Impregnation is an economic and easy wood treatment technique in flame retardancy. Phosphoric acid, ammonium polyphosphate, ammonium sulfate, boric acid, borax and zinc borate are commonly used flame retardants (Ayrilmis 2007). Chemicals with acidic character like inorganic phosphates, increase the degradation rate of wood at lower temperatures, which causes the higher char yield. Roth et al. (2007) explained also flame retardant mechanism of ammonium polyphosphate (APP). It can both change the pyrolysis reactions and diminish the degradation temperatures (Roth et al. 2007). Boric acid, borax and their mixture were used with APP as a synergist for environmentally friendly and halogen-free flame retardants (FR) in wood-high density poly(ethylene) composites (Kurt et al. 2012). The same formulations were also used in the manufacture of wood polymer composites with polypropylene. APP and boron compounds retard flame by producing carbona-

\footnotetext{
${ }^{1}$ Mugla Sitki Kocman University, Faculty of Science, Department of Chemistry, Mugla, Turkey.

${ }^{2}$ Mugla Sitki Kocman University, Faculty of Technology, Department of Wood Science and Technology, Mugla, Turkey.

${ }^{3}$ Mugla Sitki Kocman University, Koycegiz Vocational School Department of Forestry, Mugla, Turkey.

"Corresponding author: ergun69@yahoo.com

Received: 17.01.2018 Accepted: 30.08.2018
} 
ceous foam which protects the material from temperature rise (Kurt and Mengeloglu 2011). Boron compounds, such as disodium octaborate tetrahydrate (DOT), boric acid and borax are odourless, colourless, non-corrosive, cheap and non-toxic chemicals (Mohareb et al. 2011). However, the leaching of boron compounds from wood has been one of the significant problems for over years. (Obanda et al. 2008). Different FR chemicals showed various degradation mechanisms. For example, both the phosphorus and nitrogen containing FR chemicals, the initial reaction is dephosphorylation by releasing acids resulting in enhanced dehydration. Hence, second stage occurs at lower temperatures and forms char. For nitrogen and halogens based FR, the halogen free radicals scavenge the other radicals and inhibit the formation of volatiles and so, retard the weight loss (Gao et al. 2006).

In this study, different phosphate, sulfate and chloride salts and their mixtures were impregnated into Oriental beech wood samples. The thermal degradation temperatures and char yields of different inorganic salts impregnated wood samples were determined by thermogravimetric analysis (TGA). Simply, TGA is a thermal characterization method in which the mass loss of sample is measured as a function of temperature.

\section{MATERIALS AND METHODS}

\section{Materials}

Wood samples obtained from sapwood of Oriental beech (Fagus orientalis L.) timber free of knots and excessive cross-grain was machined into narrow strips. The strips were carefully chosen for having the same annual ring and then cut into small pieces prior to milling. Wood flour was prepared by grinding the small wood pieces in a Wiley mill to pass a 50 mesh screens. Before treatment of ground particles, the samples were stored at $65 \%$ relative humidity and $20^{\circ} \mathrm{C}$ for two weeks. Diammonium hydrogen phosphate, $\left(\mathrm{NH}_{4}\right)_{2} \mathrm{HPO}_{4}$, (ACS Reagent, Merck), dipotassium hydrogen phosphate, $\mathrm{K}_{2} \mathrm{HPO}_{4}(98 \%$, Sigma Aldrich), ammonium chloride, $\mathrm{NH}_{4} \mathrm{Cl}$, (99,5\% Sigma) and ammonium sulfate, $\left(\mathrm{NH}_{4}\right)_{2} \mathrm{SO}_{4},(99 \%$, Sigma Aldrich) were used without further purification.

\section{Impregnation method}

Aqueous solutions of the wood preservatives having concentration of $3 \%$ were prepared using distilled water for the impregnation procedure. The wood flour approximately $100 \mathrm{~g}$ was immersed in the solutions at $60^{\circ} \mathrm{C}$ for $2 \mathrm{~h}$. The treated wood specimens were subsequently dried at $60^{\circ} \mathrm{C}$ until they had the unchangeable weight. The impregnation procedure of wood flour and wood specimens was similar as described by Jiang et al. (2010) and Yunchu et al. (2000). Then, wood specimens were moisture conditioned for two weeks at $20^{\circ} \mathrm{C}$ and $65 \%$ relative humidity.

\section{Thermal analysis}

Differential thermal analysis (DTA) and thermogravimetric analysis (TG) were performed under nitrogen atmosphere with heating rate of $10^{\circ} \mathrm{C} / \mathrm{min}$ and a purge rate of $50 \mathrm{~mL} / \mathrm{min}$ (Argon) using a LABSYS TG-DTA analyzer between room temperature to $600^{\circ} \mathrm{C}$. For each individual experiment, $10 \mathrm{mg}$ of sample was analyzed, and the weight loss of the sample was recorded continuously. Derivative TG (DTG) curves were obtained from TG curve as a function of time.

\section{RESULTS AND DICUSSION}

As highly combustible materials, wood and wood products have been treated with different chemicals in order to provide fire retardant properties. Various approaches have been used to make wood more resistant to fire such as chemical modification of wood, in situ deposition of polymers and the impregnation of insoluble inorganic compounds into wood. (Marney and Russell 2008) Among these techniques, the impregnation of different phosphate, sulphate, amine, amide and boron compounds is the most common, fast, economic and effective method (Keskin et al. 2009). Attempts have been made to formulate more environmentally friendly 
chemicals against thermal degradation and fire retardancy.

The thermal stabilities and decomposition temperatures of treated and untreated beech wood (control) samples were investigated and their TGA/DTG thermograms were given in Figure 1 and Figure 2. The TGA data for all samples was also tabulated in Table 1.

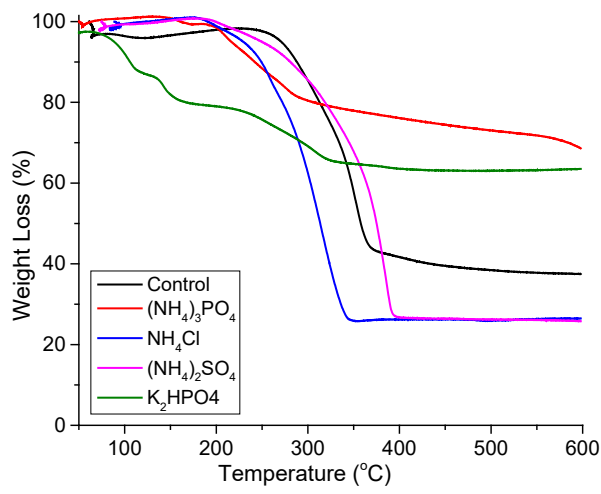

Figure 1: TGA curves for beech wood and treated beech wood with different inorganic salts.

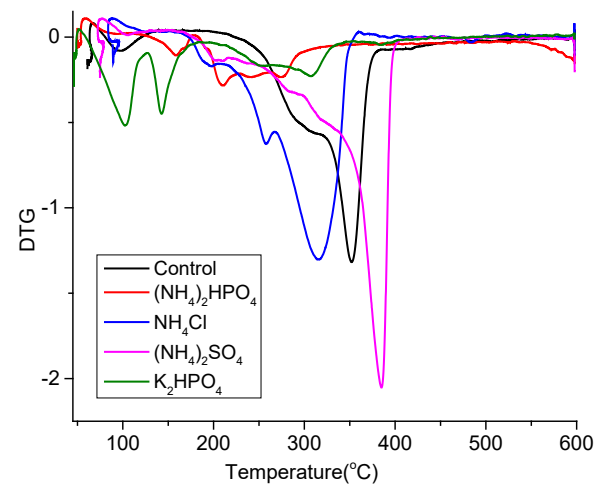

Figure 2: DTG curves for untreated and treated beech wood samples.

According to TGA thermogram of untreated beech wood, the weight loss takes place at three distinct steps with a maximum rate of weight loss at $351^{\circ} \mathrm{C}$. The first loss of weight at $97^{\circ} \mathrm{C}$ is due to the evaporation of adsorbed water and dehydration of untreated wood sample. The onset of peak at around $200^{\circ} \mathrm{C}$ shows the starting point of decomposition of wood. Typically, wood has a larger shoulder region due to degradation of hemicelluloses before the degradation of cellulose (Beall and Eickner 1970, Jeske et al. 2012). Hemicellulose has an amorphous structure and degradation extends through the peak at $300^{\circ} \mathrm{C}$ (Figure 2). Then, the sharp decrease in weight can be seen at $351^{\circ} \mathrm{C}$ due to the splitting of cellulose macromolecules. At temperatures above $351^{\circ} \mathrm{C}$, degradation of lignin starts and the residue consists primarily of charcoal from lignin decomposition (Slopiecka et al. 2011). 
Table 1: TGA data of all treated samples and untreated beech wood.

\begin{tabular}{|c|c|c|c|}
\hline Sample & $\mathbf{T}_{\mathrm{i}}\left({ }^{\circ} \mathrm{C}\right)$ & $\mathrm{T}_{\text {main }}\left({ }^{\circ} \mathrm{C}\right)$ & $\%$ Char yield \\
\hline Control & 291 & 351 & 38 \\
\hline$\left(\mathrm{NH}_{4}\right)_{2} \mathrm{HPO}_{4}^{*}$ & 211 & 275 & 69 \\
\hline$\left(\mathrm{NH}_{4}\right) \mathrm{Cl}$ & 257 & 316 & 27 \\
\hline$\left(\mathrm{NH}_{4}\right)_{2} \mathrm{SO}_{4}$ & 283 & 384 & 26 \\
\hline $\mathrm{K}_{2} \mathrm{HPO}_{4}$ & 256 & 306 & 64 \\
\hline$\left(\mathrm{NH}_{4}\right)_{2} \mathrm{HPO}_{4}+\left(\mathrm{NH}_{4}\right) \mathrm{Cl} * *$ & 258 & 300 & 47 \\
\hline$\left(\mathrm{NH}_{4}\right)_{2} \mathrm{HPO}_{4}+\left(\mathrm{NH}_{4}\right)_{2} \mathrm{SO}_{4}$ & 292 & 345 & 41 \\
\hline$\left(\mathrm{NH}_{4}\right)_{2} \mathrm{HPO}_{4}+\mathrm{K}_{2} \mathrm{HPO}_{4}$ & 253 & 290 & 80 \\
\hline $\mathrm{K}_{2} \mathrm{HPO}_{4}+\left(\mathrm{NH}_{4}\right) \mathrm{Cl}$ & 256 & 323 & 67 \\
\hline $\mathrm{K}_{2} \mathrm{HPO}_{4}+\left(\mathrm{NH}_{4}\right)_{2} \mathrm{SO}_{4}$ & 254 & 273 & 71 \\
\hline$\left(\mathrm{NH}_{4}\right)_{2} \mathrm{SO}_{4}+\mathrm{NH}_{4} \mathrm{Cl}$ & 259 & 300 & 29 \\
\hline
\end{tabular}

**For two types of salts, the total salt concentration is $3 \%$, e.g. $1,5 \%\left(\mathrm{NH}_{4}\right)_{2} \mathrm{HPO}_{4}+1,5 \%\left(\mathrm{NH}_{4}\right) \mathrm{Cl}(\mathrm{w} / \mathrm{w})$

TGA of inorganic salt impregnated wood samples revealed that degradation took place between $200^{\circ} \mathrm{C}$ and $400^{\circ} \mathrm{C}$. The $\%$ char yield is the solid residual mass percent at $600^{\circ} \mathrm{C}$. For all treatments, the main peaks migrate to the lower temperatures, especially for hemicellulose degradation. For $\mathrm{NH}_{4} \mathrm{Cl}$ and $\left(\mathrm{NH}_{4}\right)_{2} \mathrm{SO}_{4}$ salts the hemicellulose was degraded at $197^{\circ} \mathrm{C}$ and $206^{\circ} \mathrm{C}$, respectively. Also, $\mathrm{NH}_{4} \mathrm{Cl}$ and $\left(\mathrm{NH}_{4}\right)_{2} \mathrm{SO}_{4}$ salts treated samples showed less \% char than that of untreated (control) sample. Similar observations were reported for ammonium sulfamate and $\mathrm{NH}_{4} \mathrm{Cl}$ treated wood samples. These salts can sublime completely below $400^{\circ} \mathrm{C}$ and especially for $\mathrm{NH}_{4} \mathrm{Cl}$, the structural change (from $\alpha$ to $\beta$ form) takes place at $184^{\circ} \mathrm{C}$ (Browne and Tang 1962). Wood treated with one of the ammonium salts began to pyrolyze at much lower temperatures and was much more extensively volatilized than untreated wood at $250^{\circ} \mathrm{C}$. Browne and Tang (1963) also explained this increased volatilization by effects of ammonium salts. All of the ammonium salts are possible sources of ammonia. For the phosphate salts (e.g. $\left(\mathrm{NH}_{4}\right)_{2} \mathrm{HPO}_{4}$ and $\mathrm{K}_{2} \mathrm{HPO}_{4}$ ) initial decomposition products appeared as a new peaks at $159^{\circ} \mathrm{C}$ and $143^{\circ} \mathrm{C}$, respectively. Hence, the impregnation of inorganic salts changed the TGA curves and main decomposition temperatures were lowered (Table 1). This diminishment can be attributed to the filler effect. The inorganic salts were doped into the wood and they reduce the intermolecular interactions between the macromolecules of wood (hemicellulose and cellulose chains). The effect of inorganic salts on thermal behavior of wood samples was also explained by Müller-Hagedorn et al. (2003). Only $\left(\mathrm{NH}_{4}\right)_{2} \mathrm{SO}_{4}$-treated beech wood samples showed a bit higher $\mathrm{T}_{\text {main }}=384^{\circ} \mathrm{C}$ degradation temperature (Table1), but its char yield was lower than that of untreated wood sample. Elyounssi et al. (2012), declared that the peaks temperatures corresponds to cellulose and hemicellulose are both shifted and lowered in intensity. The main reason is that the decreasing the crystallinity. Hence, the chemicals added to wood reduce the interactions between the chains and the crystallinity. The highest $\%$ char yields were obtained from $\left(\mathrm{NH}_{4}\right)_{2} \mathrm{HPO}_{4}$ and $\mathrm{K}_{2} \mathrm{HPO}_{4}$-treated samples and phosphate containing salts had a char-forming catalytic effect on wood protection against fire. However, $\mathrm{NH}_{4} \mathrm{Cl}$-impregnated wood lost more than $73 \%$ of its initial weight and $\mathrm{NH}_{4} \mathrm{Cl}$ salt is not effective in char formation (Table 1).

Mixtures of $\left(\mathrm{NH}_{4}\right)_{2} \mathrm{HPO}_{4}, \mathrm{~K}_{2} \mathrm{HPO}_{4}, \mathrm{NH}_{4} \mathrm{Cl}$ and $\left(\mathrm{NH}_{4}\right)_{2} \mathrm{SO}_{4}$ salts $(1: 1 ; \mathrm{w} / \mathrm{w})$ aqueous solutions at $3 \%(\mathrm{w} / \mathrm{w})$ concentration were prepared and then impregnated into wood samples. TGA and DTG thermograms of control and different salt mixtures impregnated samples were presented in Figure 3 and Figure 4, respectively. The chemical structures and physical properties of used salts are different and these variations can result in different fire protection mechanisms in wood. The general mechanism is to cool the flame (with the releasing of water) or to cause a lack of oxygen by releasing nitrogen / halogen or to inhibit oxygen diffusion by forming a carbonaceous protective layer on the burning wood (Roth et al. 2007, Su et al. 1998). Flame retardants can also act as diluent for combustible gases or reduce the pyrolysis temperature and form more char (Tomak et al. 2012). 


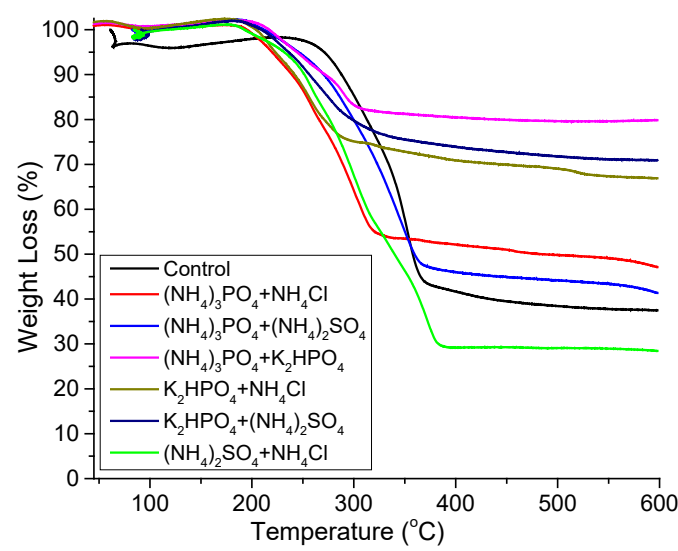

Figure 3: TGA curves for beech wood and treated samples with different salt mixtures.

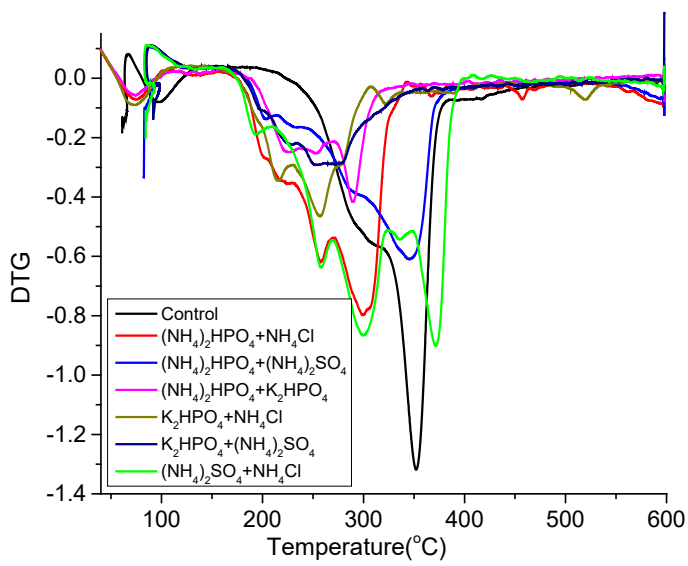

Figure 4: DTG curves for untreated and treated beech wood samples with salt mixtures.

Different mixtures impregnated wood samples degraded between $165-400^{\circ} \mathrm{C}$ (Figure 3). The formulation of $\left(\mathrm{NH}_{4}\right)_{2} \mathrm{HPO}_{4}-\mathrm{NH}_{4} \mathrm{Cl}$ mixture reduce the initial $\left(\mathrm{T}_{\mathrm{i}}\right)$ and main $\left(\mathrm{T}_{\text {main }}\right)$ degradation temperatures $\left(258^{\circ} \mathrm{C}\right.$ and $300^{\circ} \mathrm{C}$ ) and also the weight of residue from this formulation was lower than the others. Similar result was obtained from $\left(\mathrm{NH}_{4}\right)_{2} \mathrm{SO}_{4}-\mathrm{NH}_{4} \mathrm{Cl}$ mixture and both degradation temperatures $\left(259^{\circ} \mathrm{C}\right.$ and $\left.300^{\circ} \mathrm{C}\right)$ and char yield $(29 \%)$ were decreased. There was a new peak appeared in DTG curve at around $371{ }^{\circ} \mathrm{C}$ corresponds to the decomposition of lignin parts of wood. Besides, with the addition of phosphate salts $\left(\left(\mathrm{NH}_{4}\right)_{2} \mathrm{HPO}_{4}\right.$ or $\mathrm{K}_{2} \mathrm{HPO}_{4}$, into the formulation, the char yields were increased regardless of the type of phosphates (Table 1). The reason for this increment is the higher amount of carbonization reactions between phosphate and lignin. The highest char yield can be observed for $\left(\mathrm{NH}_{4}\right)_{2} \mathrm{HPO}_{4}-\mathrm{K}_{2} \mathrm{HPO}_{4}$ mixture impregnation $(80 \%)$. Again, the main wood degradation peaks were shifted to the lower temperatures due to the filler effect. Same phenomena was observed for the inorganic filler added poly(lactic acid) and the crystallinity and degradation temperatures decreased (Liu et al. 2014). Hence, the $\left(\mathrm{NH}_{4}\right)_{2} \mathrm{HPO}_{4}$ and $\mathrm{K}_{2} \mathrm{HPO}_{4}$ salts were found to be successful inorganic salts in fire retardancy. It seems to have been widely accepted that effective flame retardants lower the onset temperature of decomposition, lower the amount of volatile combustibles and promote the char formation (Yorulmaz 2006, Stimely and Blankenhorn 1985). At above $300^{\circ} \mathrm{C}$ cellulose depolymerization is very fast and anhydro-sugars, 
randomly linked oligosaccharides and levoglucosan are formed (Shafizadeh 1982). Collard and Blin explained the char as an aromatic polycyclic structure. Intra- and intermolecular rearrangements lead to higher crosslinking and thermal stability of the residue (Collard and Blin 2014). Consequently, there is a potential synergy between the $\left(\mathrm{NH}_{4}\right)_{2} \mathrm{HPO}_{4}$ and $\mathrm{K}_{2} \mathrm{HPO}_{4}$ salts which resulted in increasing in char yield du to the interactions between the lignin derived product and promoting residue from cellulose and hemicellulose. Furthermore, the other combinations which were used in this study achieved a reasonable degree of fire retardancy.

\section{CONCLUSIONS}

Formulation of environmentally friendly flame retardants for wood protection against fire is a very complex and challenging issue for researches. Four different phosphate, sulphate and chloride containing salts and their mixtures were impregnated into the Oriental beech wood in this work. The thermal behaviors of impregnated wood samples were evaluated by TGA. The Oriental beech untreated wood started to degrade at around $200^{\circ} \mathrm{C}$ with a maximum at $291^{\circ} \mathrm{C}$ for hemicellulose and then continued to degradation of cellulose component at $350^{\circ} \mathrm{C}$. The incorporation of inorganic salt changed the degradation mechanisms of woods by adding more steps and lowered the peak temperatures. The $\left(\mathrm{NH}_{4}\right)_{2} \mathrm{HPO}_{4}$ and $\mathrm{K}_{2} \mathrm{HPO}_{4}$ salts increased the char yield from $38 \%$ (control) to $69 \%$ and $64 \%$, respectively. Their $1: 1(\mathrm{w} / \mathrm{w} \%$ ) mixture, improved the thermal stability of wood. Phosphates salts containing formulation showed the best performance in $\%$ char yield $(80 \%)$ due to the higher amount of carbonization reactions between phosphate and lignin. However, $\mathrm{NH}_{4} \mathrm{Cl}$ and $\left(\mathrm{NH}_{4}\right)_{2} \mathrm{SO}_{4}$ salts did not contribute to achieve higher thermal stability of wood. Also, they created a significant reduction in char yield when compared with untreated wood.

\section{REFERENCES}

Ayrilmis, N. 2007. Effect of fire retardants on internal bond strength and bond durability of structural fiberboard. Building and Environment 42(3): 1200-1206.

Beall, F.C.; Eickner, H.W. 1970. Thermal degradation of wood components: a review of the literature. U.S. Forest Products Laboratory, 1-26.

Browne, F.L.; Tang, W.K. 1962. Thermogravimetric and differential thermal analysis of wood and wood treated with inorganic salts during pyrolysis. Fire Research Abstracts and Reviews 4(1 and 2): 76-91.

Browne, F.L.; Tang, W.K. 1963. Effect of Various Chemicals on Thermogravimetric Analysis of Ponderosa Pine. USDA. Forest Products Laboratory. Research Paper FPL-RP-6:1-23

Collard, F.X.; Blin, J. 2014. A review on pyrolysis of biomass constituents: Mechanisms and composition of the products obtained from the conversion of cellulose, hemicelluloses and lignin. Renewable and Sustainable Energy Reviews 38:594-608.

Elyounssi, K.; Collard, F.X.; Mateke, J.A.N.; Blin, J. 2012. Improvement of charcoal yield by two-step pyrolysis on eucalyptus wood: A thermogravimetric study. Fuel 96(1):161-167.

Gao, M.; Sun, C.Y.; Wang, C.X. 2006. Thermal Degradation of wood Treated with Flame Retardants. Journal of Thermal Analysis and Calorimetry 85(3): 765-769.

Jeske, H.; Schirp, A.; Cornelius, F. 2012. Development of a thermogravimetric analysis (TGA) method for quantitative analysis of wood flour and polypropylene in wood plastic composites (WPC). Thermochimica Acta 543: 165-171.

Jiang, J.; Li, J.; Hu, J.; Fan, D. 2010. Effect of nitrogen phosphorus flame retardants on thermal degradation of wood. Construction and Building Materials 24(12): 2633-2637.

Kartal, S.N.; Hwang, W.J.; Imamura, Y. 2007. Water absorption of boron-treated and heat-modified wood. Journal of Wood Science 53(5): 454-457. 
Keskin, H.; Atar, M.; Izciler M. 2009. Impacts of impregnation chemicals on combustion properties of the laminated wood materials produced combination of beech and poplar veneers. Construction and Building Materials 23(2): 634-643.

Kurt, R.; Mengeloglu, F. 2011. Utilization of boron compounds as synergists with ammonium polyphosphate for flame retardant wood-polymer composites. Turkish Journal of Agriculture and Forestry 35(2): $155-163$

Kurt, R.; Mengeloglu, F.; Meric, H. 2012. The effects of boron compounds synergists with ammonium polyphosphate on mechanical properties and burning rates of wood-HDPE polymer composites. European Journal of Wood and Wood Products 70(1-3): 177-182.

Liu, X.; Wang, T.; Chow, L.C.; Yang, M.; Mitchell, J.W. 2014. Effects of Inorganic Fillers on the Thermal and Mechanical Properties of Poly(lactic acid). International Journal of Polymer Science 2014(827028): $1-8$.

Marney, D.C.O.; Russell, L.J. 2008. Combined Fire Retardant and Wood Preservative Treatments for Outdoor Wood Applications - A Review of the Literature. Fire Technology 44(1): 1-14.

Mohareb, A.; Thevenon, M.F.; Wozniak, E.; Gerardin, P. 2011. Effects of polyvinyl alcohol on leachability and efficacy of boron wood preservatives against fungal decay and termite attack. Wood Science and Technology 45(3): 407-417.

Müller-Hagedorn, M.; Bockhorn, H.; Krebs, L.; Müller, U. 2003. A comparative kinetic study on the pyrolysis of three different wood species. Journal of Analytical and Applied Pyrolysis 68(Special Issue): 231249.

Obanda, D.N.; Todd F.; Shupe, H.; Barnes, M. 2008. Reducing leaching of boron-based wood preservatives -A review of research. Bioresource Technology 99(15):7312-7322.

Ohashi, H.; Igarashi, S.; Nagaoka, T. 2018. Development of wood structural elements for fire resistant buildings. Journal of Structural Fire Engineering 9(2): 126-137.

Roth, M.; Schwarzinger, C.; Mueller, U.; Schmidt, H. 2007. Determination of reaction mechanisms and evaluation of flame retardants in wood-melamine resin-composites. Journal of Analytical and Applie Pydrolysis 79(1-2): 306-312.

Salman, S.; Petrissans, A.; Thevenon, M.F.; Dumarcay, S.; Perrin, D.; Pollier, B.; Gerardin, P. 2014. Development of new wood treatments combining boron impregnation and thermomodification: effect of additives on boron leachability. European Journal of Wood and Wood Products 72(3): 355-365.

Shafizadeh, F. 1982. Introduction to pyrolysis of Biomass. Journal of Analytical and Applied Pyrolysis 3(4): 283-305.

Slopiecka, K.; Bartocci, P.; Fantozzi, F. 2011. Thermogravimetric analysis and kinetic study of poplar wood pyrolysis. Third International Conference on Applied Energy. 16-18 May Perugia, Italy.

Stimely G.L.; Blankenhorn P.R. 1985. Effects of Species, Specimen Size and Heating Rate on Char Yield and Fuel Properties. Wood and Fiber Science 17(4): 477-489.

Su, W.Y.S.; Hata, T.; Nishimiya, K.; Imamura, Y.; Ishihara, S. 1998. Improvement of fire retardancy of plywood by incorporating boron or phosphate compounds in the glue. Journal of Wood Science 44(2): 131136.

Thevenon, M.-F.; Tondi, G.; Pizzi, A. 2009. High performance tannin resin-boron wood preservatives for outdoor end-uses. European Journal of Wood and Wood Products 67(1): 89-93.

Tomak, E.D.; Baysal, E.; Peker, H. 2012. The effect of some wood preservatives on the thermal degradation of Scots pine. Thermochimica Acta 547: 76-82.

Yorulmaz S. Y. 2006. Investigation of Emissions and Combustion Kinetics of Waste Wood Sam- 
ples with Thermal and Spectral Methods. MSc Thesis: 70-127. Available online https://etd.lib.metu.edu.tr/ upload/12607570/index.pdf (access 30/08/2018)

Yunchu, H.; Peijang, Z.; Songsheng, Q. 2000. TG-DTA studies on wood treated with flame retardants. Holz als Roh- und Werkstoff 58(1): 35-38. 